\title{
Nilai Gizi dan Organoleptik Bakso Daging Ayam Yang Ditambahkan Tepung Kacang Koro Pedang (Canavalia gladianta)
}

\section{Nutritional and Organoleptic Value of Chicken Meatballs Andded with Koro Pedang Flour (Canavalia gladianta)}

\author{
Ni Made Andry Kartika*, Alimuddin \\ Fakultas Peternakan, Universitas NahdlatulWathanMataram, \\ J1. Kaktus No. 1-3 (0370) 641275 Mataram \\ *corresponding author, email: andry.kartika@ymail.com
}

Manuscript received: 26-10-2020. Accepted: 23-12-2020

\begin{abstract}
ABSTRAK
Bakso adalah makana umum dimasyarakat dan memiliki nilai gizi yang baik. Koro pedang dapat digunakan sebagai bahan pengikat selain memiliki kualitas dan protein yang lebih baik dibanding tepung tapioca. Penelitian ini bertujuan untuk mengetahui pengaruh penambahan tepung kacang koro pedang terhadap nilai gizi dan nilai organoleptik bakso daging ayam. Metode yang digunakan dalam penelitian ini adalah ekperimental dengan Rancangan Acak Lengkap terdiri dari 5 perlakuan dan diulang sebanyak 5 kali yaitu K0 (control), K1 (bakso ayam + tepung kacang koro pedang 20\%), $\mathrm{K} 2$ (bakso ayam + tepung kacang koro pedang 25\%), K3(bakso ayam + tepung kacang koro pedang $30 \%$ ), K4(bakso ayam + tepung kacang koro pedang 35\%). Varibel yang diukur adalah nilai gizi atau komposisi kimia (kadar air, kadar abu, kadar lemak dan protein kasar) dan nilai organoleptik bakso ayam dengan penambahan tepung kacang koro pedang (canavalia gladiate). Hasil penelitian yang telah dilakukan diperoleh nilai gizi menunjukan hasil yang signifikan atau semua perlakuan (K1, K2, dan K4) berbeda sangat nyata $(\mathrm{P}>0.01)$ untuk protein kasar, serat kasar, lemak kasar dan abu. Sementra untuk kadar air dalam perlakuan ini tidak ditemukan hasil yang signifikan. Nilai tertinggi rata-rata ditunjukkan pada perlakuan K4 untuk protein, lemak kasar, serat kasar dan abu. Untuk nilai organoleptik menunjukkan hasil signifikan $(\mathrm{P}<0.05)$ pada perlakuan $\mathrm{K} 1$ untuk rasa, warna, tekstur, dan penerimaan. Sementara untuk aroma tidak signifikan.
\end{abstract}

Kata kunci:bakso; gizi; komposisi; organoleptic; tepung

\begin{abstract}
Meetball is a common food in society and has good nutritional volue. Sword koro can be used as a binder besides having better quality and protein than tapioca flour. This study aims to determine the effect koro pedang flour to the nutritional value and organoleptic value $f$ chicken meatballs. The method used in the study was a completely randomized designconsisting of 5 teatments and repeated 5 times, namely: KO (control), K1 (chicken meatballs + koro pedang flour 20\%), K2 (chicken meatballs + koro pedang flour 25\%), K3 (chicken meatballs + koro pedang flour 30\%) and K4
\end{abstract}


(chicken meatballs ++ koro pedang flour $35 \%$ ). The variables measured ware the nutritional value or chemical composition (moisture content, ash content, fat content, and crure protein), and the organoleptic value of chicken meatballs with the addition of koro pedang flour (Canavalia Gladiante). Analysis of the data used the analysis of variance based on completely randomized design CRD), from the results of different analyzes followed by the LSD test. The results showed that the nutritional value showed very significant results or all treatments (K1, K2, K3 dan K4) were significantly different $(\mathrm{P}>0.01)$ for crude protein, crude fiber, crude fat and ash. Maenwhile, for the water content in this treatment, no significant results were found. The highest average value is shown in the K4 tretment for protein, crude fat, crude fiber and ash. The organoleptic value showed significant results $(\mathrm{P}<0.05)$ on the $\mathrm{K} 1$ treatment for taste, color, texture and acceptance. Maenwhile, the aroma is insignificant because the aroma of the meatballs added with koro flour has a very strong and distinctive aroma.

Key words: composition; meatballs;flours; nutritional; organoleptic

\section{PENDAHULUAN}

Bakso merupakan produk olahan daging yang telah dihaluskan terlebih dahulu dan dicampur dengan bumbu, tepung, dan kemudian dibentuk seperti bola-bola kecil lalu direbus dalam air panas. Menurut Badan Satandar Nasional (BSN) Indonesia bakso adalah produk olahan daging dengan kadar daging tidak kurang dari 50\% yang umumnya berbentuk bulatan dan dicampur dengan pati atau sedelia dengan atau tanpa penambahan bahan makanan lain serta bahan tambahan makanan yang diizinkan. Pendistribusian bakso di wilayah Indonesia sudah sangat luas sehingga produk ini memegang peranan penting dalam penyebarluasan protein hewani bagi konsumsi zat gizi masyarakat Indonesia. Ditinjau dari aspek gizi, bakso merupakan makan yang mempunyai kandungan protein hewani, mineral dan vitamin yang tinggi.

Bakso yang ada di pasaran umumnya merupakan bakso yang berasal dari daging sapi, walaupun demikian bakso juga dapat dibuat dari daging ternak lainnya seperti daging ayam broiler. Daging ayam dikenal memiliki kandungan gizi yang cukup baik karena mengandung protein sebesar 27 gr, lemak sebesar 14 gr, kalori sebesar $239 \mathrm{kcal}$, kalsium sebesar $15 \mathrm{mg}$, zat besi 1,3 mg dan vitamin A sebesar $161 \mathrm{IU}(\mathrm{USDA}$ et al, 2018). Selain itu, daging ayam memiliki rasa dan aroma yang enak dan diskusi banyak orang sehingga daging ayam dapat diolah menjadi berbagai macam olahan makanan. Nilai manfaat daging meningkat dengan dimasak, digoreng, disate, diasap dan diolah menjadi produk lain yang menarik antara lain komet, sosis, dendeng, abon, nugget dan bakso.

Proses pembuatan bakso pada umumnya menggunakan tepung tapioca yang digunakan sebagai perekat (Windayani,2010). Adapun penambahan tepung sebagai filler bakso berguna untuk memperbaiki testur, meningkatkan daya ikat air, menurunkan penyustan akibat pemasakan dan meningkatkan elastisitas produk. Dalam rangka penganekaragaman pangan, fungsi ini bias digantikan dengan tepung lian seperti koro pedang. Tanaman koro pedang (Canavalia gladianta) telah lama dikenal di Indonesia, namun kompetisi antar jenis tanaman menyebabkan tanaman ini tersisih dan jarang ditanam dalam skala luas. Hal ini mungkin disebabkan karena biji koro pedang tidak dapat dimakan secara langsung karena akan menimbulkan rasa pusing. Secara tradisional tanaman koro pedang digunakan untuk pupuk 
hijau, polong muda, digunakan untuk sayur dimasak seperti irisan kacang buncis (Anonim et al. 2012).

Beberapa jenis tepung kacang koro yang dapat digunakan sebagai bahan pengikat adalah jenis tepung kacang koro pedang yang mempunyai kualitas dan protein lebih baik dibandingkan jenis tepung kacang koro lainnya, karena memiliki kandungan protein yang tinggi. Kacang koro pedang mempunyai kandungan karbohidrat $(66,1 \%)$ dan protein yang tinggi $(27,4 \%)$ serta lemak yang lebih rendah (2,9\%) (Primawestri dan Rustanti, 2014). Selain itu, Dini dan Dian (2011) dalam penelitian menunjukan bahwa sosis yang berbahan dasar tepung kacang koro sebagai pengikat memiliki kandungan gizi yang tidak kalah dengan kacang kedelai, perbandingan protein dari kacang koro sebanyak 27.4\%. Dan kacang kedelai sebanyak $39.4 \%$. Sehubungan dengan hal itu dirasa perlu untuk meningkatkan nilai gizi dan organoleptik bakso ayam jika dilakukan penambahan tepung kacang koro pedang (Canavalia gladianta). Artikel ini merupakan catatan penelitian yang diharapkan mampu memperbaiki kualitas pangan dan dapat diterima oleh masyarakat sehingga memperkaya keanekaragaman pangan hasil ternak.

\section{Lokasi dan Waktu Penelitian}

\section{BAHAN DAN METODE}

Penelitian ini merupakan percobaan eksperimental yang dilakukan di laboratorium teknologi pengolahan hasil ternak(TPHT) UNW Mataram dan Laboratorium Ilmu Nutrisi dan Makanan Ternak (INMT) Fakultas Peternakan Universitas Mataram yang akan dilaksanakan selama 6 bulan.

\section{Materi Penelitian}

Tepung koro yang digunakan pada penelitian ini adalah kacang koro yang didapat di wilayah Masbagek Kabupaten Lombo Timur. Biji kacang koro memiliki ciri - ciri berbentuk bulat kecil berwarna putih agak pipih dengan aroma yang khas.

\section{Metode Penelitian}

Metode yang digunakan dalam penelitian ini adalah ekseprimental laboratorium, dimana percobaan diatur menurut rancangan acak lengkap (RAL), dengan 5 perlakuan yaitu control, K1 (daging ayam+ tepung koro pedang 20\%), K2(daging ayam + tepung koro pedang 25\%), K3( daging ayam + tepung koro pedang 30\%) dan K4(daging ayam + tepung koro pedang $35 \%$ ) dengan diulang sebanyak 5 kali.

\section{Pelasksanaan Percobaan}

Tahapan - tahapan yang dilakukan dalam penelitian ini meliputi; mempersipkan alat alat dan bahan yang akan digunakan dalam penelitian. Antara lain; Pembuatan tepung koro pedang dan Persipaan Pembuatan Bakso.

\section{a. Pembuatan tepung koro pedang}

Tepung biji koro dibuat dengan menggunakan metode ekstraksi kering merupakan suatu metode pembuatan tepung yang paling mudah dan praktis. Ekstaksi kering dilakukan dengan 
cara pengeringan setelah bahan mengalami proses pembersihan dan pemotongan atau penghalusan kasar.

\section{b. Bakso daging Ayam}

Pembuatan bakso dalam penelitian ini membutuhkan $20 \mathrm{~kg}$ daging ayam dan $9 \mathrm{~kg}$ tepung kacang koro pedang. Bumbu yang digunakan dalam pembuatan bakso yaitu 1,5\% garam, 20 es batu, tepung koro sesua perlakukan, 0,25\% lada, 0,5\% bawang putih, 0,25\% msg dan $0,25 \%$ STPP.

\section{Variabel Penelitian}

Variable penelitian yang diamatai antara lain;

- Uji komposisi kimia atau nilai gizi yang dilakukan dengan menggunakan analisis proksimat meliput kadar air, kadar abu, kadar lemak dan protein.

- Uji organaloptik dilakukan dengan munggunkan 20 orang penelis yang tergolong terlatih untuk memberikan penilaian terhadap warna, aroma, tesktur, bentuk, rasa dan penerimaan panelis terhadap bakso dengan penambahan tepung kocang koro dengan metode hedonic scale(skala hedonic). Adapun criteria penilaian bakso dengan penambahan tepung kacang koro terdiri dari sifat - sifat untuk organoleptik:

Rasa; sangat enak (>70-90), enak (>50-70), kurang enak (>30-50), tidak enak (10-30). Warna; sangat menarik (>70-90), menarik (>50-70), kurang menarik (>30-50), tidak menarik (10-30). Aroma; sangat sedap (>70-90), sedap (>50-70), kurang sedap $(>30-$ 50), tidak sedap (10-30). Tekstur; sangat baik (>70-90), baik (>50-70), kurang baik (>30-50), tidak baik (10-30). Penerimaa; sangat suka (>70-90), suka (>50-70), kurang suka (>30-50), tidak suka (10-30).

\section{Analisis data}

Data dianalisis dengan anova pada tingkat kepercayaan 5\% dan $1 \%$, jika berbeda nyata dilanjutkan dengan uji lanjut terkecil.

\section{Tepung Kacang Koro}

\section{HASIL DAN PEMBAHASAN}

Uji kualitas awal yang dilakukan sebelum dicampur dengan bakso ayam adalah melihat kualitas kimia dan fisik dari tepung kacang koro. Hasil uji dapat dilihat pada Tabel 1 Dari Tabel 1 diketahui kualitas kimia dan kualitas fisik pada tepung kacang koro pedang. Kualitas kimia atau nilai gizi setelah dianalisa menggunakan uji proksimat diperoleh hasil tertinggi pada kandungan serat kasar dan protein tepung koro yaitu 37.25\% (serat) dan $29.03 \%$ (protein). Selain itu kadar abu dan kandungan air memiliki nilai rendah yaitu $4.48 \%$ (abu) dan 7.155 (air).

Kualitas fisik yang diamati pada tepung kacang koro pedang adalah warna, bau atau aroma dan tekstur. Dari tabel 1 diketahui warna tepung koro pedang yang dibuat adalah berwarna putih yang agak sedikit kecoklatan dengan aroma khas koro dan tekstur yang halus. Warna merupakan atribut yang penting pada industri makanan. Drajat putih merupakan 
indeks warna sampel yang sering digunakan untuk menilai mutu tepung. Produk tepung tepungan biasanya diharapkan memiliki derajat putih yang tinggi. Adanya perlakuan pendahuluan dapat menurunkan derajat putih tepung koro pedang secara signifikan (Wahyuningtias dkk, 2018). Rekasi millard menyebabkan perubahan warna bubuk menjadi coklat, selain itu semakin tinggi konsentrasi asam yang digunakan untuk merendam bahan, maka $\mathrm{pH}$ larutan juga semakin turun sehingga dapat menghambat aktivitas enzim fenolase dikarenakan enzim fenolase tidak dapat bekerja secara maksimal. Hal ini mengakibatkan semakin tinggi pula nilai kecerahan tepung yang dihasilkan (Mutmainahdkk.2013).

Tabel 1 Kualitas Kimia Dan Kualitas Fisik Tepung Kacang Koro

\begin{tabular}{ll}
\hline Kulitas Kimia & Persentase $(\%)$ \\
\hline Protein & 29.03 \\
Lemak & 27.40 \\
Abu & 4.48 \\
Air & 7.15 \\
Serat Kasar & 37.25 \\
Kualitas Fisik & \\
\hline Kecerahan (warna) & Putih sedikit coklat \\
Bau & Khas kacang koro(sedikit menyengat seperti kopi) \\
Tekstur & Halus seperti tepung \\
\hline \multicolumn{2}{c}{ Data primer diolah tahun 2020}
\end{tabular}

Pembuatan tepung koro pedang dan pengujian kulitas kimia serta fisiknya dilakukan karena tepung koro tidak ada beredar di seluruh wilayah Nusa Tenggara Barat (NTB), padahal dari hasil diatas tepung koro pedang bias dijadikan salah satu sumber pangan yang memiliki kualitas gizi yang baik sebagai salah satu bentuk ketahanan pangan. Selain itu analisa pada tepung koro diperlukan untuk menghindari bias dalam penelitian yang akan dilakukan. Sehingga dengan hasil yang baik pada tabel 1 maka dapat dilanjutkan untuk tahap selanjutnya.

\section{Nilai Gizi Bakso Kacang Koro}

Hasil penelitian menunjukan bahwa terdapat perbedaan sangat nyata pada nilai gizi bakso ayam yang telah dicampur tepung koro pada tingkat kepercayaan ( $\mathrm{P}>0.01)$. hal ini dapat dilihat dari tabel 2 dibawah ini;

Berdasarkan tabel 2 diperoleh hasil yang sangat signifikan atau semua perlakukan berbeda sangat nyata $(\mathrm{P}>0.01)$. Nilai protein kasar pada setiap perlakukan $(\mathrm{K} 1, \mathrm{~K} 2, \mathrm{~K} 3$ dan K4) menunjukan hasil yang sangat baik, dengan rata - rata yang paling tinggi pada K4 sebesar 19,63\%. Umumnya protein dibedakan menjadi dua yaitu protein hewani dan protein nabati. Dari hasil penelitian diatas (tabel 2) kombinasi protein hewani dan nabati seperti daging ayam dan tepung koro yang berbentuk bakso ini menjadi sangat baik sebagai produk olahan dalam peningkatan kualitas pangan bagi masyarakat luas.

Lemak kasar pada perlakuan K1, K2, K3 dan K4 menunjukan hasil yang lebih baik dari K0 (Tabel 2). Hal ini sangat baik karena lemak berperan selain sebagai energy, melarutkan vitamin A, D, E dan $\mathrm{K}$ serta menyediaan asam lemak esensial bagi tubuh 
(Anonim, 2012) juga kandungan lemak dalam makanan sebagai penambah citra rasa dalam makanan sehingga akan semakin enak dan gurih.

Tabel 2. Hasil Rata - Rata Uji Proksimat Pada Bakso Yang Ditambah Kacang Koro

\begin{tabular}{lllllll}
\hline $\begin{array}{l}\text { Nilai } \\
\text { Gizi }\end{array}$ & $\begin{array}{l}\text { Kontrol } \\
(\text { K4) }\end{array}$ & $\begin{array}{l}\text { 20\% kacang } \\
\text { koro }(\text { K1) }\end{array}$ & $\begin{array}{l}\text { 25\% kacang } \\
\text { koro(K2) }\end{array}$ & $\begin{array}{l}\text { 30\% kacang } \\
\text { koro(K3) }\end{array}$ & $\begin{array}{l}\text { 35\% kacang } \\
\text { koro(K4) }\end{array}$ & $\begin{array}{l}\text { LSD } \\
(\mathbf{1 \% )})\end{array}$ \\
\hline $\begin{array}{l}\text { Protein }(\%) \\
\text { Lemak }\end{array}$ & $9.65 \pm 0.35^{\mathrm{a}}$ & $11.19 \pm 0.47^{\mathrm{b}}$ & $14.32 \pm 0.52^{\mathrm{c}}$ & $16.40 \pm 0.45^{\mathrm{d}}$ & $19.63 \pm 0.61^{\mathrm{e}}$ & 0.780 \\
Kasar (\%) & $0.64 \pm 0.03^{\mathrm{a}}$ & $0.84 \pm 0.06^{\mathrm{b}}$ & $0.88 \pm 0.05^{\mathrm{c}}$ & $1.00 \pm 0.08^{\mathrm{d}}$ & $1.06 \pm 0.13^{\mathrm{e}}$ & 0.127 \\
$\begin{array}{l}\text { Serat Kasar } \\
(\%)\end{array}$ & & & & & & 0.085 \\
Abu (\%) & $0.08 \pm 0.00^{\mathrm{a}}$ & $0.27 \pm 0.04^{\mathrm{b}}$ & $0.50 \pm 0.02^{\mathrm{c}}$ & $0.73 \pm 0.04^{\mathrm{d}}$ & $0.78 \pm 0.10^{\mathrm{e}}$ & \\
Air (\%) & $73.91 \pm 0.60^{\mathrm{a}}$ & $0.21 \pm 3.10^{\mathrm{b}}$ & $0.30 \pm 0.02^{\mathrm{c}}$ & $0.41 \pm 0.05^{\mathrm{d}}$ & $0.48 \pm 0.04^{\mathrm{e}}$ & 0.024 \\
\hline
\end{tabular}

Keterangan: angka-angka pada masing-msing kolom yang diikuti huruf yang sama berbeda tidak nyata menurut LSD $1 \%$

Serat kasar dan abu juga sama menunjukan hasil sangat signifikan $(\mathrm{P}>0.01)$ pada setiap perlakuan (K1, K2, K3 dan K4). Sudarmaji dkk 1994) menyatakan bahwa penentuan abu total sangat berguna sebagai parameter nilai gizi bahan makanan, adanya kandungan abu yang tidak larut dalam asam yang cukup tinggi menunjukkan adanya pasir atau kotoran yang kain. Jadi semakin rendah kadar abu dalam makanan, maka semakin baik bahan makanan tersebut.

Sementara untuk persentase kadar air dalam perlakuan ini tidak ditemukan hasil yang signifikan $(\mathrm{P}<0.001)$ atau $\mathrm{K} 0$ memiliki nilai lebih tinggi. Air merupakan salah satu unsur penting dalam bahan pangan, meskipun bukan sumber nutrient namun keberadaannya sangat esensial dalam kelangsungan proses biokimiawi organism hidup. Sehingga sering dianggap sebagai factor penentu dalam daya simpan suatu produk pangan. Kandungan air yang tidak terlalu tinggi ini justru sengat bagus. Menurut Collins dan Walter (1982) suatu ketahanan dan keawetan suatu produk pangan dipengaruhi oleh kadar air. Artinya bakso ayam dengan tambahan kacang koro ini dapat bertahan lebih lama.

Dalam penelitian ini terlihat bahwa pemberian 35\% tepung koro pedang mendapatkan hasil yang paling berbeda sangat nyata $(\mathrm{P}>0.01)$, hal ini sangat baik untuk dikembangkan sebagai sumber pangan protein yang berkualitas. Secara umum diketahui bahwa bakso merupakan makanan yang sangat digemari dan memiliki nilai gizi yang baik, hanya saja penggunaan bahan campuran lainnya cenderung mengurangi niali gizi bakso. Dengan penambahan tepung koro pedang terbukti nilai gizi bakso ayam malah meningkat bila dibandingkan sebelum penambahan, bahkan bias dibilang jauh diatas kontrol (K0). Kandungan protein, lemak, serat dan abu sangat dibutuhkan tubuh terutama untuk proses pertumbuhan anak. Dengan modifikasi bakso ayam ini bersama kacang koro, diharap dapat mingkatkan komsumsi protein pada masyarakat Indonesia dan bias menjadi solusi pangan berkualitas dengan harga terjangkau tentunya. 


\section{Nilai Ogranoleptik}

Hasil penelitian menunjukan bahwa terdapat perbedaan nyata pada nilai gizi bakso ayam yang telah dicampur tepung koro pada tingkat kepercayaan $(\mathrm{P}>0.05)$. Hal ini dapat dilihat pada Tabel 3.

Tabel 3. Rata - Rata Nilai Organoleptik Bakso Ayam Yang Telah Dicampur Tepung Koro Pedang

\begin{tabular}{|c|c|c|c|c|c|c|}
\hline \multirow[b]{2}{*}{$\begin{array}{c}\text { Uji } \\
\text { Organoleptik }\end{array}$} & \multicolumn{5}{|c|}{ Perlakuan } & \multirow[t]{2}{*}{ LSD $5 \%$} \\
\hline & $\begin{array}{l}\text { Kontrol } \\
\text { (K0) }\end{array}$ & $\begin{array}{l}20 \% \text { kacang } \\
\text { koro(K1) }\end{array}$ & $\begin{array}{l}25 \% \\
\text { kacang } \\
\text { koro(K2) }\end{array}$ & $\begin{array}{l}30 \% \\
\text { kacang } \\
\text { koro(K3) }\end{array}$ & $\begin{array}{l}35 \% \text { kacang } \\
\text { koro(K4) }\end{array}$ & \\
\hline Rasa (\%) & $.0 \pm 7.53^{\mathrm{a}}$ & $74.0=$ & $68.0 \pm 4.10^{\mathrm{a}}$ & & & 1.74 \\
\hline Warna (\%) & $46.0 \pm 15.9^{a}$ & $50.0 \pm 9.73^{b}$ & $54.5 \pm 8.87^{c}$ & $61.5 \pm 8.13^{\mathrm{e}}$ & $61.0 \pm 9.12^{\mathrm{d}}$ & 3.25 \\
\hline Tekstur & $42.0 \pm 7.68^{a}$ & $64.0 \pm 5.03^{\mathrm{ab}}$ & $66.0 \pm 3.84^{\mathrm{e}}$ & $65.0 \pm 3.84^{\mathrm{d}}$ & $64.0 \pm 3.84^{\mathrm{ab}}$ & 1.50 \\
\hline Aroma (\%) & $1.0 \pm 4.89^{\mathrm{a}}$ & 62.0 & $62.3 \pm 7$ & $58.3 \pm$ & 59. & 2.37 \\
\hline Penerimaan $(\%)$ & $61.5 \pm 4.89^{\mathrm{a}}$ & $66.8 \pm 7.12^{\mathrm{c}}$ & $64 \pm 5.98^{\mathrm{b}}$ & $59 \pm 9.98^{\mathrm{a}}$ & $59 \pm 9.94^{\mathrm{a}}$ & 2.26 \\
\hline \multicolumn{7}{|c|}{$\begin{array}{l}\text { Keterangan: - Angka-angka pada masing-msing kolom yang diikuti huruf yang sama berbeda tidak nyata menurut LSD } \\
\text { 5\%. } \\
\text { Rasa; sangat enak }(>70-90) \text {, enak }(>50-70) \text {, kurang enak }(>30-50) \text {, tidak enak }(10- \\
\text { 30).; sangat menarik }(>70-90) \text {, menarik }(>50-70) \text {, kurang menarik }(>30-50) \text {, tidak } \\
\text { menarik }(10-30) \text {. Aroma; sangat sedap }(>70-90) \text {, sedap }(>50-70) \text {, kurang sedap }(>30- \\
\text { 50), tidak sedap }(10-30) \text {. Tekstur; sangat baik }(>70-90) \text {, baik }(>50-70) \text {, kurang baik } \\
\quad(>30-50) \text {, tidak baik }(10-30) \text {. Penerimaan; sangat suka }(>70-90) \text {, suka }(>50-70) \text {, } \\
\text { kurang suka }(>30-50) \text {, tidak suka }(10-30) \text {. }\end{array}$} \\
\hline
\end{tabular}

Dari Tabel 3 diperoleh bahwa untuk rasa diperoleh hasil signifikan $(\mathrm{P}>0.05)$ pada perlakuan K1 sebesar 74\% dengan kategori sangat enak. Sementara untuk perlakuan K2, K3 dan K4 menunjukkan rasa pada kategori hanya enak saja.

Warna rerata kesukaan penalis terhadap warna bakso menunjukan hasil signifikan disemua perlakuan, dimana hasil warna yang menarik terlihat pada perlakuan K1, K2, K3 dan K4. Dalam pengamatan terlihat pemberian tepung koro pedang membuat warna bakso ayam yang umumnya putih menjadi agak coklat kemerahan seperti bakso sapi. Hal ini tentu terlihat menarik untuk dilihat oleh panelis.

Tabel 3 diatas menunjukan bahwa tingkat tekstur bakso yang diberi perlakuan tengung koro pedang menunjukkan hasil signifikan $(\mathrm{P}>0.05)$ dimana nilai tekstur yang tertinggi yaitu pada perlakuan K2 penambahan tepung koro sebesar $66 \%$.

Aroma bakso ayam yang dicampur tepung koro tidak terlihat menunjukan hasil yang signifikan ( $\mathrm{P}<0.05)$. Menurut Kartika dkk (1988), aroma sukar untuk diukur sehingga biasanya menimbulkan pendapat yang berlaianan dalam menilai kualitas aromanya. Dijelaskan lebih lanjut bahwa perbedaan pendapat tersebut disebabkan karena setiap orang memiliki intensitas penciuman yang tidakn sama meskipun mereka dapat membedakan aroma. Bakso dengan tepung koro pedang ini termasuk dalam kategori aroma yang sedap tetapi cukup menyangat sehingga untuk yang memiliki penciuman sensitif menunjukan respon yang suka atau kebalikannya bahkan bias sangat terganggu. 
Dari 20 penelis yang digunakan diperoleh hasil bahwa tingkat penerimaan produk bakso ayam yang diberi tambahan tepung koro pedang sebagai peningkatan kualitas produk diperoleh hasil bahwa perlakuan $\mathrm{K} 1$ dan $\mathrm{K} 2$ menunjukan hasil yang signifikan $(\mathrm{P}>0.05)$ dan tergolong pada kreteria suka jika dilihat dari hasil rerata keseluruhannya.

Dari hasil kesimpulanan nilai organoleptik terlihat untuk penerimaan panelis pada produk bakso dengan tambahan tepung koro pedang ini yang paling baik ditunjukkan pada penambahan K1. Ini bisa disebabkan karena produk dalam golongan olahan produk asin seperti sumber protein akan sanagt sensitive terutama pada rasa aromanya dibandingkan olahan proudk yang manis seperti kue. Karena aroma, rasa atau tekstur dasar tepung koro yang unik sehingga jika pemberian level semakin tinggi maka akan sangat menyengat juga aroma dan rasa tepung koro tersebut. Hasil ini tentu berbeda dengan nilai gizinya yang menunjukan hasil terbaik pada perlakuan $\mathrm{K} 4$.

\section{KESIMPULAN}

Kesimpulan yang didapat dari pemberian tepung koro pedang dalam bakso ayam menunjukan bahwa hasil yang berbeda sangat nyata $(\mathrm{P}>0.01)$ pada perlakuan $\mathrm{K} 4$ untuk kandungan gizinya seperti pada protein kasar, lemak kasar, serat kasar dan abu. Sementara, untuk nilai organoleptik menunjukan hasil signifikan ( $\mathrm{P}>0.05)$ pada perlakuan $\mathrm{K} 1$ untuk rasa, warna, tektur dan penerimaan. Sementara untuk aroma tidak signifikan karena aroma bakso yang ditambah tepung koro sangat menyengat dan khas.

\section{Ucapan Terimaksih}

Peneliti mengucapkan terimaksih kepada kemenristekdikti atas dana yang diberikan melalui penelitian skim peneliti dosen pemula tahun pelaksanaan tahun 2020 dengan nomor kontrak 012/LPPM/UNW/V/2020.

\section{DAFTAR PUSTAKA}

Anonym.2020.USDA. https://ndb.nal.usda.gov/ndb/search/list?qlookup=05009. Akses pada tanggal 10-10-2020.

Anonim. 2012. http://.Puslittan. Bogor. Net/Downloads/. Budidaya Kacang Koro.Pdf.

Badan Standar Nasional (BSN). Bakso Daging. (SNI). 01-3818-1995. Jakarta; (BSN), 1995.

Collins, W.W dan W.M.Walter, Jr. 1982. Potential Fore Increasing Nutritional Value Of Sweet Potato. In Sweet Potato Proc. Of the first int. Symp. R. L. Villareal and D. griggs (eds) P 355-63. AVRDC.Shanhua, Taiwan.

Dini, G dan Dian, A. 2011. Potensi Koro Pedang (Canavlia Gladiante) dan saga pohon (Adhenanthera Povonia) sebagai alternative susbsitusi bahan baku tempe. Program Aktivitas Mahasiswa. Bogor.

Kartika, Bambang, Hastuti, pudji dan wahyu Supartono. 1988. Pedoman Uji Inderawi Bahan Pangan. Pusat Antar Universitas Pangan dan Gizi UGM. Yogyakarta.

Mutmainah, F., Rahadian, D.A.M dan Amanto, B.S. 2013. Kajian karakteristik fisikokimia tepung sukun (Artocarpus Comunis) termodifikasi dengan variasi lama perendamanan dan konsentrasi asam asetat. Jurnal Teknosains Pangan 2; 4, 46-53. 
Primawestri, M.A., Rustanti, N., 2014, Pengaruh Pemberian Susu Koro Pedang (Canavalia ensiformis) terhadap Kadar Kolesterol Total dan Trigliserida Serum Tikus Sprague dawley Hiperkolesterolemia, Artikel Ilmiah Ilmu Gizi Fakultas Kedokteran Universitas Diponegoro. Semarang.

Sudarmaji dkk. 1994. Analisa Bahan Makanan Dan Pertanian. Liberty Yogyakarta. Yogyakarta.

United State Departement of Agriculture(USDA). 2018. USDA National Nutrient Database for Standart Reference. https://fdc.nal.usda.gov//. Diakses tanggal 5-5-2019

Wahyuningtyas, arba'abu Ies, Yoga Pratama dan Bhakti Etza Setiani. 2018. Karakteristik Fisik Tepung Kacang Koro Pedang. Jurnal Pangan dan Agroindustri Vol.6 No. 1:2833.

Windayani. 2010. Kandungan Boraks dan Cemaran Mikroba pada Bakso Daging Sapi Di Kabepaten Tanggerang. Tesis. Bogor; Institusi Pertanian Bogor. 